\title{
Psychological Characteristics of Entrepreneurship of College Students in China
}

\author{
Hua Zhang ${ }^{1}$, Ying Zhang ${ }^{2}$ \\ ${ }^{1}$ School of Psychology, Southwest University, Chongqing, China \\ ${ }^{2}$ School of Computer and Information Science \& Software, Southwest University, Chongqing, China \\ Email: zh17295@126.com,myworld@swu.edu.cn
}

Received November $27^{\text {th }}, 2012$; revised January $6^{\text {th }}, 2013$; accepted February $4^{\text {th }}, 2013$

\begin{abstract}
The study investigated the psychological characteristics of entrepreneurship of 829 college students in China by questionnaire. The psychological characteristics include five aspects: entrepreneurial capacity, entrepreneurial belief, entrepreneurial consciousness, entrepreneurial motivation, and entrepreneurial determination. In the five factors, the entrepreneurial consciousness of college students is the highest, and the other four are almost at the same level. There is significant difference on entrepreneurial belief, consciousness, and motivation in different gender of students. Also there is significant difference on entrepreneurial consciousness in different major students and on entrepreneurial motivation in different degree students. However, the college students only with high entrepreneurial consciousness are not enough to succeed in business. The other four psychological characteristics are not only essential to entrepreneurship, but also necessary to their future professional development. College students should have a lot of preparation and accumulation on the other four psychological characteristics of entrepreneurship, and give much more effort to improve them.
\end{abstract}

Keywords: Psychological Characteristics; Entrepreneurship; College Students; Entrepreneurs

\section{Introduction}

The entrepreneurship is more and more becoming an inseparable part of the global DNA, and it should become reasonable, or more self-evident choice (Schramm, 2009). Peter Drucker, American management master, he pointed out, entrepreneurial employment was one of the main driving force of economic development in the United States and the core of the success of its employment policy. In China, to ensure sustained economic development and enhance the national innovation, and ease the growing social pressure on employment, successful entrepreneurial activity is critical. College students are a vital force to participate in entrepreneurial activities (Gong \& Xie, 2009). They will not only become job seekers, but also job creators. How is the current situation of their entrepreneurship?

According to the Global Entrepreneurship Monitor Report of China in 2007, Chinese entrepreneurial activity had remained active, full entrepreneurial index rose gradually from $12.3 \%$ in 2002 to $16.4 \%$ in 2007, and the main body of entrepreneurship was still those who did not access to higher education (Yin, 2008). Although relevant national policies promote the entrepreneurial enthusiasm of college graduates, the proportion of their entrepreneurship is still very low. The failure of their entrepreneurship is the proportion of $99 \%$ (Jiang, 2010). Even some policies supported, why are the college students not active enough in entrepreneurship and easy to fail?

Facing the fierce competition in job market, college students should find a new path and entrepreneurial employment is an effective and challenging way. Maybe the college students do not really understand the entrepreneurship. Developing entrepreneurial skills and entrepreneurial spirit of college students must become the basic objectives of higher education (Gong \&
Xie, 2009). If college students want to succeed in business, the external environment will be very important, but the most fundamental is that what kind of psychological characteristics they should have. We explored the psychological characteristics of entrepreneurship of college students on the basis of study about successful entrepreneurs.

\section{Literature Review}

The entrepreneurship referred to that one or more individuals braved the economic risks creating new organizations, and used new technologies or innovative technology to create value for others (Schramm, 2006). Similarly, the entrepreneurship was to find and capture opportunities, create innovative products, services, and achieve their potential value (Hisrich, 2006). Nearly two decades, the entrepreneurship of college students have been attracted many scholars. The people should master the three "education passport", the first is the academic passport, that is cultural and scientific knowledge; the second is the professional passport, that is, professional knowledge and technology; the third is proving a person's sense of professionalism and the ability to open up, that is entrepreneurship education passport. If a person does not have the third passport, his academic and professional knowledge and technology will not play well, even nothing (Zhang, Yu, Fan et al., 2011).

\section{Psychological Characteristics of Entrepreneurs}

Certain personality traits will contribute to the choice of entrepreneurship and its ultimate success. By the questionnaire, entrepreneurs were found that their achievement motivation, risk-taking tendency, innovative score were significantly higher 
than the other two groups, managers and working-class (Carland, Hoy, Boulton et al., 1984). Another study also used the questionnaire and compared the personality of entrepreneurs and ordinary people (the unemployed, retirees, students, women) and working-class, found that entrepreneurs had higher levels of individual responsibility and hard-working quality (Beugelsdijk \& Noorderhaven, 2005). Five personalities of entrepreneurs were put forward in one book named the cause of revolution, i.e. willing to take the risk; can distinguish good business ideas; the determination and confidence; resolute courage; willing to work longer to achieve success (Jiang, 2010).

The researchers also explored their cognitive characteristics of the entrepreneurship (Yan, Ye, \& Chen, 2008). Individual's perception and interpretation of style, access to information, decision-making played an important role in the entrepreneurship, and the influence of individual cognitive style on opportunity recognition, risk identification, as well as the characteristics of cognitive changes in various start-up stage were clarified (Mitchell, 2002). Scholars proposed application the entrepreneurial cognition research to explore how entrepreneurs think and make decisions, and pointed out that the possession of information and individual cognitive nature were two important factors for the decision of entrepreneurs to grasp entrepreneurial opportunities (Shane \& Venkataraman, 2000). In summary, entrepreneur's unique psychological qualities generally include: achievement motivation, risk-taking tendency, innovation, locus of control, selfefficacy, leadership qualities, responsibility, openness to experience (Stewart, Warren Jr. et al., 1997; Wijbenga \& van Witteloostuijn, 2007). These study provided a reference for the psychological characteristics of entrepreneurship of college students.

\section{Psychological Characteristics of Entrepreneurship of College Students}

In China, the study of psychological characteristics of entrepreneurship of college students mainly referred to the quality. The quality determined the success or failure of college students' entrepreneurship. Entrepreneurial qualities included the personality qualities, intellectual quality, cultural quality, mental quality and physical quality (Liu, 2002). The entrepreneurial quality of the college students were divided into four aspects: the first was entrepreneurial ideas, including the desire, determination, enthusiasm, responsibility, spirit of adventure and entrepreneurship concept; the second was entrepreneurial capacity, including the organization and management capabilities, ability of high efficiency to work, interpersonal skills, capability of responding emergency, innovation, insight force, the relevant technical expertise and excellent thinking skills, etc; the third was entrepreneurial characteristics, including physical and psychological quality and responsibility; the fourth was entrepreneurial knowledge and skills, including mastering relevant policies ,regulations and theory (social, occupational, etc.) knowledge and skills on entrepreneurship (Chen, Lei, \& Cao, 2006).

Some scholars studied the problem from other perspectives. The entrepreneurial consciousness of college students included entrepreneurial emotion, entrepreneurial needs and motivations, entrepreneurial value, entrepreneurial risk and entrepreneurial quality, and the main content of the consciousness was entrepreneurial emotion (Li, Z., Li, X. F., \& Wan, 2010). The entre- preneurial competency model of college students consisted of three dimension that was learning ability, relationships ability and concepts ability (Zhang, Yang, \& Fan, 2010).

However, where the psychological characteristics of successful entrepreneurship do stem from? How to make them more effective and more meaningful? We will start with the psychological characteristics of successful entrepreneurs building entrepreneurial theory of college students.

\section{Research Design}

The psychological characteristics of entrepreneurship mean one's psychological factors of starting in business successfully. We studied it by the questionnaire. The questionnaire items had the following four sources: firstly, we created the theoretical conception of psychological characteristics of successful entrepreneurship. Then, we interviewed 5 college students who were in successful entrepreneurship, and collected some views about psychological characteristics of successful entrepreneurship. Subsequently, the interview or autobiography of many successful entrepreneurs was studied, and some psychological characteristics were summarized. Lastly, previous research on entrepreneurship gave a reference for it. After the items were collected, some experts were invited to evaluate them in small symposium. Then 50 items of Liket 5 point self rating scale were determined after several modifications and adjustments. These items were arranged randomly, and asked twenty successful entrepreneurs evaluate them, and choose only one in five answers from "very important", "more important", "in general", "less important", "not important". The answer was accordingly scored by 5 to 1 points. 34 items were chose which $80 \%$ entrepreneurs (16 entrepreneurs) evaluated more than 4 points and the questionnaire was compiled.

The questionnaire survey was conducted with random sampling method, and the participants were college students from six colleges or universities in Chongqing and Chengdu in China. 829 valid questionnaires were collected.

\section{Results Analysis}

\section{Exploratory Factor Analysis}

The applicability test of exploratory factor analysis was conducted, and the results showed that the KMO value was 0.908 , and the value of Bartlett test was $7476.750(\mathrm{df}=561, p=$ 0.000 ). There were common factors in the correlation matrix of groups and suitable for factor analysis.

Five factors were extracted by the method of principal component analysis and orthogonal rotation according to the Eigen value rules, gravel inspection rules, and the original theoretical conception. The items which the value of the factor loadings was less than 0.3 were deleted. Also the item which the value of the factor loadings was greater than 0.3 simultaneously in the above two factors were deleted. The 31 items were ultimately retained, and they could explain $42.258 \%$ of the total variance (see Table 1).

\section{Overall Analysis on Psychological Characteristics of Entrepreneurship of College Students}

From Table 2, we can see the 5 factors and their corresponding items. The first factor named entrepreneurial capacity includes 10 items. The second factor named entrepreneurial 


\section{H. ZHANG, Y. ZHANG}

Table 1.

The value of the factor loadings and contribution of various factors of psychological characteristics of entrepreneurship.

\begin{tabular}{ccccc}
\hline Factors & Eigen value & Item numbers & Factor loading values & Contribution rate \\
\hline Entrepreneurial capacity & 8.132 & 10 & $0.467-0.648$ & $23.917 \%$ \\
Entrepreneurial belief & 1.888 & 7 & $0.430-0.634$ & $5.554 \%$ \\
Entrepreneurial consciousness & 1.796 & 5 & $0.504-0.651$ & $5.283 \%$ \\
Entrepreneurial motivation & 1.290 & 5 & $0.487-0.765$ & $3.793 \%$ \\
Entrepreneurial determination & 1.262 & 4 & $0.318-0.693$ & $3.711 \%$ \\
\hline
\end{tabular}

Table 2.

Psychological characteristics of entrepreneurship of college students $(\mathrm{N}=829)$.

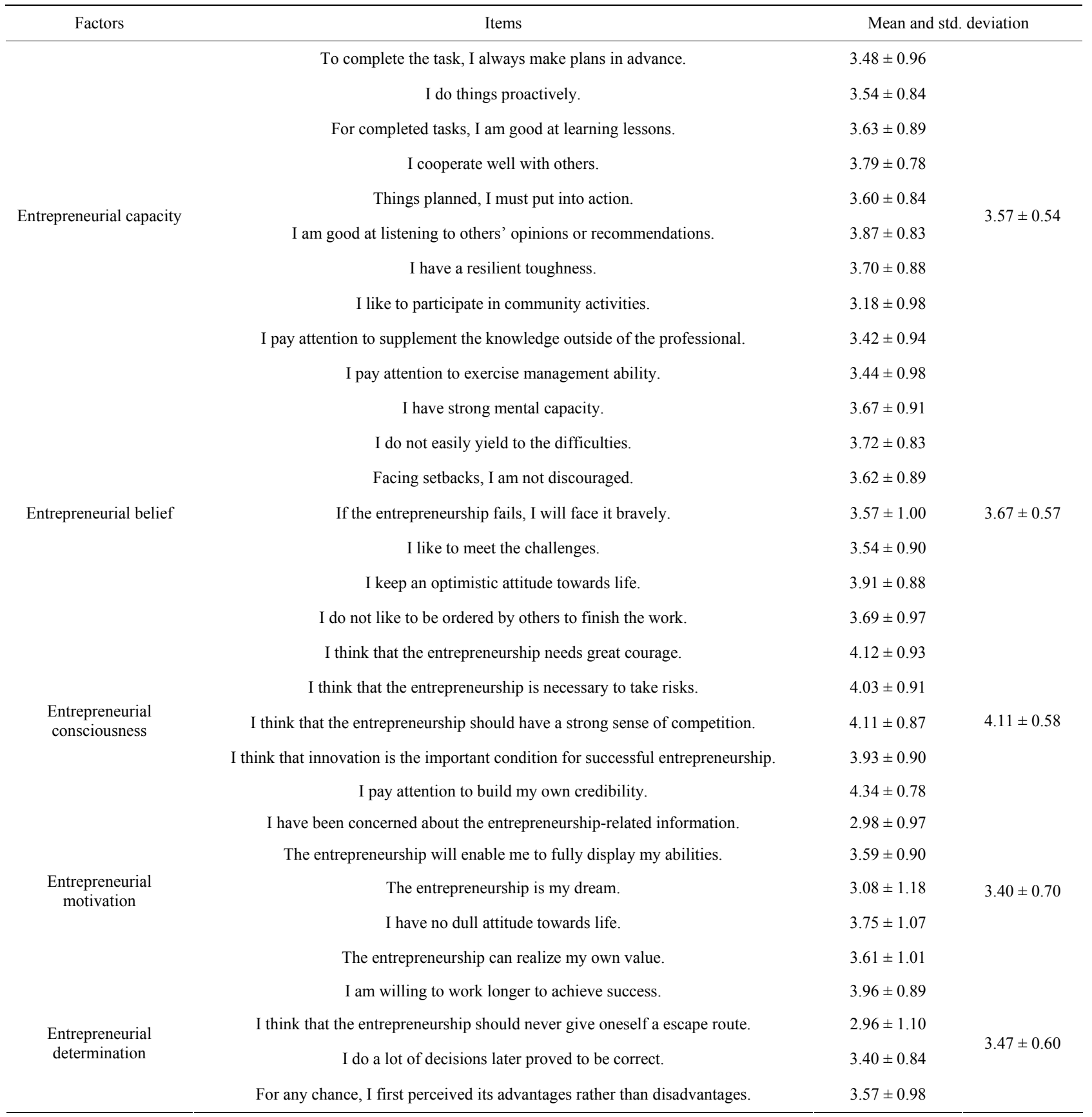


belief includes 7 items. The third factor named entrepreneurial consciousness includes 5 items. The fourth factor named entrepreneurial motivation includes 5 items. The fifth factor named entrepreneurial determination includes 4 items.

In the five factors, the mean of entrepreneurial consciousness is the highest, and more than 4 . The students have a positive understanding of entrepreneurship, and courage, taking risks, sense of competition and innovation are indispensible to entrepreneurship.

The means of last four factors are almost at the same level, from 3.40 to 3.67, and less than 4. The means of items of entrepreneurial belief are almost close to the mean of the factor. In the factor of entrepreneurial capacity, the means of some items are relatively low, such as participating in community activities, supplementing the knowledge outside of the professional, exercising management ability, and making plans in advance. That capacity is not only essential to entrepreneurship, but also necessary to their future professional development. However, they give less effort to improve this capacity.

In the factor of entrepreneurial motivation, the means of some items are relatively low, such as "The entrepreneurship is my dream", "I have been concerned about the entrepreneurship-related information". The mean of the later is even less than 3. These students are not keen on entrepreneurship, and are not ready for it.

From Table 2, we also can see that in the factor of entrepreneurial determination, the mean of the item of "I think that the entrepreneurship should never give oneself an escape route" is only 2.96 , less than 3 . The mean of the item of "I do a lot of decisions later proved to be correct" is also relatively low. Many students are lack of real courage for entrepreneurship, and maybe they just want to try, are not really determined, and they do not exercise their decision-making ability.

\section{Difference Analysis on Psychological Characteristics of Entrepreneurship of Different Types of Students in Colleges}

There is significant difference on certain factors in different types of students in colleges. Table 3 lists psychological char- acteristics of entrepreneurship of different gender of students in colleges. There is significant difference on three factors in different gender of students $(p<0.005, p<0.01)$.The entrepreneurial belief of male students is significantly higher than female students'. Their entrepreneurial motivation is also significantly higher than female students'. But in entrepreneurial consciousness, female students are significantly higher than male students.

Table 4 lists psychological characteristics of entrepreneurship of different major of students in colleges. There is significant difference on entrepreneurial consciousness in different major of students $(p<0.005)$, and students of the arts major are significantly higher than the students of the science major.

Table 5 lists psychological characteristics of entrepreneurship of different degree of students in colleges. There is significant difference on entrepreneurial consciousness in different degree of students $(p<0.005)$, and junior college students are significantly higher than the undergraduate students.

\section{Discussion}

\section{The Entrepreneurial Consciousness of College Students Is Strong, but They Are Lack of Preparation for Entrepreneurship}

From the means of psychological characteristics of entrepreneurship, the entrepreneurial consciousness is the highest. The other four factors are almost at the same level. The entrepreneurial consciousness includes awareness and attitudes on entrepreneurship of college students. It plays an important role on the entrepreneurship, and only college students have it, they will understand entrepreneurship, pay attention to it, and try to realize their business. But only this characteristic is not enough to succeed in business and a lot of preparation and accumulation are necessary.

One survey found 694 college students had the following characteristics by the method of questionnaire in 10 universities in China: they had distinctive characteristics of opportunity on entrepreneurial need and motivation; they had a good entrepreneurial spirit and a strong entrepreneurial desire, but were lack of the entrepreneurial quality, their own entrepreneurial prepa-

Table 3.

Psychological characteristics of entrepreneurship of different gender of students in colleges.

\begin{tabular}{|c|c|c|c|c|}
\hline Factors & Gender & $\mathrm{N}$ & Mean and std. deviation & $\mathrm{t}$ \\
\hline \multirow{2}{*}{ Entrepreneurial capacity } & Male & 365 & $3.60 \pm 0.56$ & \multirow{2}{*}{$\mathrm{t}=1.784$} \\
\hline & Female & 464 & $3.54 \pm 0.53$ & \\
\hline \multirow{2}{*}{ Entrepreneurial belief } & Male & 365 & $3.74 \pm 0.60$ & \multirow{2}{*}{$\mathrm{t}=2.763^{* *}$} \\
\hline & Female & 464 & $3.63 \pm 0.55$ & \\
\hline \multirow{2}{*}{ Entrepreneurial consciousness } & Male & 365 & $4.02 \pm 0.62$ & \multirow{2}{*}{$\mathrm{t}=-3.842^{* * *}$} \\
\hline & Female & 464 & $4.17 \pm 0.53$ & \\
\hline \multirow{2}{*}{ Entrepreneurial motivation } & Male & 365 & $3.48 \pm 0.72$ & \multirow{2}{*}{$\mathrm{t}=2.680^{* *}$} \\
\hline & Female & 464 & $3.34 \pm 0.69$ & \\
\hline \multirow{2}{*}{ Entrepreneurial determination } & Male & 365 & $3.48 \pm 0.64$ & \multirow{2}{*}{$\mathrm{t}=0.268$} \\
\hline & Female & 464 & $3.47 \pm 0.57$ & \\
\hline
\end{tabular}

Note: ${ }^{* * *} p<0.005 ;{ }^{* *} p<0.01 ;{ }^{*} p<0.05$. 
Table 4.

Psychological characteristics of entrepreneurship of different major of students in colleges.

\begin{tabular}{|c|c|c|c|c|}
\hline Factors & Major & $\mathrm{N}$ & Mean and std. deviation & $\mathrm{t}$ \\
\hline \multirow[b]{2}{*}{ Entrepreneurial capacity } & Science & 259 & $3.54 \pm 0.58$ & \multirow[b]{2}{*}{$\mathrm{t}=-0.778$} \\
\hline & Arts & 569 & $3.58 \pm 0.53$ & \\
\hline \multirow{2}{*}{ Entrepreneurial belief } & Science & 259 & $3.68 \pm 0.62$ & \multirow{2}{*}{$\mathrm{t}=0.224$} \\
\hline & Arts & 569 & $3.67 \pm 0.55$ & \\
\hline \multirow{2}{*}{ Entrepreneurial consciousness } & Science & 259 & $3.99 \pm 0.62$ & \multirow{2}{*}{$\mathrm{t}=-4.025^{* * *}$} \\
\hline & Arts & 569 & $4.16 \pm 0.55$ & \\
\hline \multirow{2}{*}{ Entrepreneurial motivation } & Science & 259 & $3.41 \pm 0.72$ & \multirow{2}{*}{$\mathrm{t}=0.202$} \\
\hline & Arts & 569 & $3.40 \pm 0.70$ & \\
\hline \multirow{2}{*}{ Entrepreneurial determination } & Science & 259 & $3.50 \pm 0.67$ & \multirow{2}{*}{$\mathrm{t}=0.830$} \\
\hline & Arts & 569 & $3.46 \pm 0.57$ & \\
\hline
\end{tabular}

Note: ${ }^{* * *} p<0.005 ;{ }^{* *} p<0.01 ;{ }^{*} p<0.05$.

Table 5.

Psychological characteristics of successful entrepreneurship of different degree of students in colleges.

\begin{tabular}{|c|c|c|c|c|}
\hline Factors & Degree & $\mathrm{N}$ & Mean and std. deviation & $\mathrm{t}$ \\
\hline \multirow{2}{*}{ Entrepreneurial capacity } & Junior college & 146 & $3.53 \pm 0.55$ & \multirow{2}{*}{$\mathrm{t}=-0.946$} \\
\hline & Undergraduate & 683 & $3.57 \pm 0.54$ & \\
\hline \multirow{2}{*}{ Entrepreneurial belief } & Junior college & 146 & $3.73 \pm 0.52$ & \multirow{2}{*}{$\mathrm{t}=1.344$} \\
\hline & Undergraduate & 683 & $3.66 \pm 0.58$ & \\
\hline \multirow{2}{*}{ Entrepreneurial consciousness } & Junior college & 146 & $4.15 \pm 0.56$ & \multirow{2}{*}{$\mathrm{t}=1.072$} \\
\hline & Undergraduate & 683 & $4.10 \pm 0.58$ & \\
\hline \multirow{2}{*}{ Entrepreneurial motivation } & Junior college & 146 & $3.57 \pm 0.66$ & \multirow{2}{*}{$\mathrm{t}=3.176^{* * *}$} \\
\hline & Undergraduate & 683 & $3.37 \pm 0.71$ & \\
\hline \multirow{2}{*}{ Entrepreneurial determination } & Junior college & 146 & $3.44 \pm 0.59$ & \multirow{2}{*}{$\mathrm{t}=-0.811$} \\
\hline & Undergraduate & 683 & $3.48 \pm 0.60$ & \\
\hline
\end{tabular}

Note: ${ }^{* * *} p<0.005 ;{ }^{* *} p<0.01 ;{ }^{*} p<0.05$.

ration and skills (Fei, 2009).In the above data, we also found the mean of entrepreneurial capacity is very low, such as participating in community activities, and so on. In fact, participating in community activities can improve students' social ability, especially the interpersonal communication skills. The social ability is the main guarantee of succeeding in business and the core ability of the entrepreneurship (Fu, Xie, \& Lan, 2009).Interpersonal communication skills should be focused on the cultivation of entrepreneurial ability (Gao \& Duan, 2009).

Greenberger \& sexton (1988) pointed out the following five reasons of entrepreneurship: firstly, they identified opportunities in the market; secondly, They believed that their management will be more efficient than others; thirdly, They have the expertise to develop into a career; fourthly, they had developed a product or service, and these can find a niche in the market; lastly, They believed that other opportunities were limited and entrepreneurship was the only way (Wang, 2007).In the entrepreneurial determination, the item of "I think that the entrepreneurship should never give oneself a escape route", similar to the last reason, has the lowest score. Visibly, the college stu- dents do not have a real determination.

Some college students' entrepreneurship succeeded, and they consciously develop their own entrepreneurial capacity in the campus. Some students paid attention to newspapers and magazines on entrepreneurship and market analysis reports, and accumulated experience in the social survey of the holiday (Le $\& \mathrm{Du}, 2011)$. In the entrepreneurial motivation, the item of "I have been concerned about the entrepreneurship-related information" has very low score, and students do not value it. So they should get adequate guidance, and successful entrepreneurs teaching their experience, visiting the successful business, and entrepreneurship simulation training should be implemented in colleges.

\section{Psychological Characteristics of Entrepreneurship of Different Types of Students in Colleges}

Except the entrepreneurial consciousness, male students are higher than female students in the other factors. Female students have high entrepreneurial consciousness, the other prepa- 
ration lower than male students. According to the Global Entrepreneurship Monitor Report of China in 2010, the entrepreneurial activities of male students were higher than female college students. Women are more like to pursue a stable life, and the entrepreneurship has high risk. While men are willing to create their own business through their own efforts, to satisfy their own sense of achievement, even going to risk ( $\mathrm{Lu} \mathrm{\&} \mathrm{Wu}$, 2011).

However, when male and female entrepreneurs were goaloriented and had the experience and enthusiasm, there were no effect of gender on entrepreneurial behavior (Hisrich \& Peter, 1989).Women and immigrants were more inclined to the entrepreneurial career path than men, or the United States citizens (O'Reilly \& Chatman 1994).

In entrepreneurial consciousness, students of the arts major are significantly higher than the students of the science major. Maybe students of the arts major have more thinking on this factor than the students of the science major, so they score higher on entrepreneurial consciousness. Junior college students are significantly higher than the undergraduate students on entrepreneurial motivation, and the former are more likely to succeed in the business than the latter. Entrepreneurs without college education are prone to failure than the entrepreneurs who have received college education (Lussier, 1995). Higher degree does not mean the more success, however, it has a great impact on entrepreneurial direction, especially in hightech industry entrepreneurs.

\section{Conclusion}

Psychological characteristics of entrepreneurship of college students by the exploratory factor analysis include five aspects: entrepreneurial capacity, entrepreneurial belief, entrepreneurial consciousness, entrepreneurial motivation, and entrepreneurial determination. In the five factors, the mean of entrepreneurial consciousness is the highest; the other four factors are almost at the same level. Those psychological characteristics are not only essential to entrepreneurship, but also necessary to their future professional development. However, they give less effort to improve and train them. There is some difference on psychological characteristics of entrepreneurship in different types of students in colleges, such as gender, major, degree, and so on.

\section{Acknowledgements}

The research is supported by the Fundamental Research Funds for the Central Universities (XDJK2009C167), 211 Project, National Key Discipline of Basic Psychology, Southwest University (NSKD11019). I would like to address my highly appreciation and thanks to it.

\section{REFERENCES}

Schramm, C. J. (2009). Everyone has equal opportunities for entrepreneurship. In Shanghai College Students Science and Technology Innovation Fund (Ed.), Entrepreneurial thinking power, Beijing: CITIC Publishing Group.

Jiang, R. G. (2010). The entrepreneurial Introduction: Entrepreneurship awareness and entrepreneurship, Beijing: Publishing House of Electronics Industry.

Gong, L., \& Xie, L. Y. (2009). Students' psychological characteristics of entrepreneurship and countermeasure. Youth Exploration, 3, 6872 .
Yin, W. (2008). The Global Entrepreneurship Monitor Report of China in 2007. URL (last checked 21 November 2008).

http:/www.chinavalue.net

Schramm, C. J. (2006). The entrepreneurial imperative. New York: Harper Business.

Hisrich, R. D. (2006). Entrepreneurship: Starting, developing, and managing a new enterprise. Shanghai: Fudan University Press.

Zhang, J. M., Yu, X. F., Fan, W. X., \& Yang, S. J. (2011). Students' entrepreneurial qualities, the ability to upgrade: Status and Prospects. Economic Research Guide, 114, 289-291.

Carland, J. W., Hoy, F., Boulton, W. R. et al. (1984). Differentiating entrepreneurs from small business owners: A conceptualization. Academy of Management Review, 9, 354-359.

Beugelsdijk, S., \& Noorderhaven, N. (2005). Personality characteristics of self-employed: An empirical study. Small Business Economics, 24, 159-167. doi:10.1007/s11187-003-3806-3

Yan, J. W., Ye, X., \& Chen, C. F. (2008). An overview on the entrepreneurial mentality of private entrepreneurs. Psychological Science, 31, 1503-1506.

Mitchell, R. K. (2002). Toward a theory of entrepreneurial cognition: Rethinking the people side of entrepreneurship research. Entrepreneurship Theory and Practice, 27, 93-104. doi:10.1111/1540-8520.00001

Shane, S., \& Venkataraman, S. (2000).The promise of entrepreneurship as a field of research. Academy of Management Review, 2, 217-226.

Stewart, W. H., Warren Jr., E. et al. (1997). Proclivity for entrepreneurship: A comparison of enterpreneurs, small owners, incorporates managers. Journal of Business Venturing, 14, 18-214.

Wijbenga, F. H., \& van Witteloostuijn, A. (2007). Entrepreneurial locus of control and competitive strategies: The moderating effect of environmental dynamism. Journal of Economic Psychology, 28, 566-589. doi:10.1016/j.joep.2007.04.003

Liu, D. Y. (2002). Entrepreneurship and life design. Wuhan: Hubei Education Press.

Chen, Y., Lei, Y. S., \&Cao, R. R. (2006). Investigation and reflection of entrepreneurship quality of college students. High Education Exploration, 4, 80-83.

Li, Z., Li, X. F., \& Wan, F. Y. (2010). The development of the questionnaire of enterprise consciousness of undergraduate. Psychological Exploration, 30, 85-89.

Zhang, J. M., Yang, S. J., \& Fan, W. X. (2010). Some thinking on improving college students entrepreneurial ability. Outside school of China, 3, 33-34.

Fei, Y. Q. (2009). Survey on the entrepreneurial quality of students of capital university. Education and Occupation, 25, 46-48.

Fu, Z. L., Xie, H. X., \& Lan, X. X. (2009). The course of entrepreneurship and success education of college students. Hefei: China Science and Technology University Press.

Gao, G. W., \& Duan, C. G. (2009). Practice and thinking of the university to promote entrepreneurship. In Shanghai College Students Science and Technology Innovation Fund (Ed.), Entrepreneurial thinking power (pp. 281-288), Beijing: CITIC Publishing Group.

Wang, Y. D. (2007). A study to identify the personality characteristics of entrepreneurs and cultivate entrepreneurship. $\mathrm{PhD}$ Thesis, Shanghai: Tongji University.

Le, S. H., \& Du, C. Y. (2011). The research of college students' entrepreneurship of Haixi rigion universities. China Electric Power Education, 28, 169.

The seventh Global Entrepreneurship Monitor (2010) Report of China was released. URL (last checked 9 January 2012). http://www.sem.tsinghua.edu.cn

Lu, J., \& Wu, J. L. (2011). Survey analysis of college students' entrepreneurship. Education Article, 2, 192-194.

Hisrich, R. D., \& Peter, M. P. (1989). Entrepreneurship. Boston: Irwin.

O'Reilly, V. A., \& Chatman, J. A. (1994). Working smarter and harder: Longitudinal study of managerial success. Administrative Science Quarterly, 39, 603-629. doi:10.2307/2393773

Lussier, R. N. (1995). Startup business advice from business owners to would-be entrepreneurs. Advanced Management Journal, 60, 10-15. 